\title{
Sustainability and Sound: Ecomusicology Inside and Outside the Academy
}

Aaron S. Allen is Associate Professor of Musicology at the University of North Carolina at Greensboro, where he also serves as the Academic Sustainability Coordinator and on the faculty committee for the Environmental Studies Program. After earning a B.A. in music and a B.S. in environmental studies from Tulane, he received the Ph.D. from Harvard with a dissertation on the nineteenth-century reception of Beethoven in Italy. He is currently coediting a volume of ecomusicology essays for Routledge and co-authoring The Tree that became a Lute: Musical Instruments, Sustainability and the Politics of Natural Resource Use (University of Illinois Press). As a winner of the Rome Prize, he spent 2011-2012 at the American Academy in Rome.

Jeff Todd Titon is Emeritus Professor of Music at Brown University, where for 28 years he directed the doctoral program in ethnomusicology. A pioneer in applied ethnomusicology, phenomenological ethnography, and ecological approaches to musical and cultural sustainability, his most recent writings concern Thoreau and soundscape ecology. In 20152016 he will hold the Basler Chair of Excellence for the Integration of the Arts, Rhetoric and Science at East Tennessee State University.

Denise Von Glahn is Professor of Musicology and Director of the Center for Music of the Americas at Florida State University. She has written on music, nature, and place in her books The Sounds of Place: Music and the American Cultural Landscape (Northeastern University Press, 2003) and Music and the Skillful Listener: American Women Compose the Natural World (Indiana University Press, 2013) and in many articles and essays. She and Sabine Feisst co-edit IUP's Music, Nature, Place series.

\section{Introduction (by Aaron S. Allen)}

Established in 2005, the Association for the Advancement of Sustainability in Higher Education (AASHE) is a North American organization that empowers institutions to become more sustainable and, in turn, create a more sustainable world through the power and influence of education. Membership is comprised of colleges and universities as a whole, not individuals; attendees at the annual conferences are primarily staff members working in facilities and operations. AASHE has, however, made successful efforts to incorporate more students and faculty, especially given the urgency presented by one of the most daunting challenges in the history of civilization: climate change. And in the context of engaging with the more local challenges that institutions face, such as the economics of sustainability and approaches to sustainability that are diverse and inclusive, AASHE is expanding its scope to include the arts and humanities.

In that context, AASHE invited me to deliver a plenary lecture at "Resiliency and Adaptation," their 2013 conference and expo. Earlier that year, I had been appointed as the Academic Sustainability Coordinator at the University of North Carolina at Greensboro (UNCG), an AASHE member institution. While I continue as a faculty member in the Department of Music Studies in the School of 
Music, Theatre and Dance (pursuing my research and service as usual and my teaching in a redirected and slightly reduced capacity), I also collaborate with the Sustainability Coordinator for Operations, Trey McDonald, and work with faculty to increase the quantity and quality of sustainability educational initiatives at UNCG. ${ }^{1}$ AASHE reached out to me, as a music scholar involved in campus sustainability, to further the dialogue between sustainability and the arts and humanities. ${ }^{2} \mathrm{I}$, in turn, reached out to two intellectuals for whom I have great respect: Denise Von Glahn (Florida State University) and Jeff Todd Titon (Brown University). The three of us collaborated in the development of a "trialogue" that provided a brief introduction to ecomusicology together with a discussion of some key issues as they relate to higher education. $^{3}$

The following is an edited and slightly elaborated (clarified, reworded, footnoted) transcript of the session held on October 7, 2013, at the AASHE conference in Nashville, Tennessee. It begins with my lecture-presentation and Denise's introductory remarks; thereafter are an informal interview between Jeff and me, a discussion among all three of us, and finally some engagement with the audience. The audience was comprised of about four hundred facilities staff, sustainability managers, environmental studies faculty and students, sustainability consultants, and others-but no music scholars. (At least, there were none to our knowledge. Furthermore, when AASHE board member Rose Harrell Johnson introduced us, she asked the audience who had heard of ecomusicology before, and about five or six raised their hands, three of whom were my UNCG colleagues!) The audience's passion for the topic was reflected in the numerous hands that went up during the Q\&A and the many kind comments the three of us received after the 75-minute session. We intend to continue future collaborations with AASHE in order to further the conversation between sustainability practitioners and ecomusicology. We therefore present this transcript as historical documentation of the event as well as a reference point in an ongoing conversation.

In the present context-that of an academic journal on music and politics-the discourse on ecomusicology brings out ramifications for activism. Our trialogue begins to outline some of the ways that practicing ecomusicology (or, more appropriately, practicing ecomusicologies ${ }^{4}$ ) is political. In the early 1990s, Philip Bohlman argued that practicing any Musicology ${ }^{5}$ is a political act, regarding both what we choose to study and what we exclude. For much of the twentieth century, Musicology "insisted on its apolitical status," and in so doing it "has come face-to-face with its own political acts." Musicology ignored "for too long the musics of women, people of color, the disenfranchised, or Others we simply do not see and hear." 7

\footnotetext{
${ }^{1}$ http://ure.uncg.edu/prod/cweekly/2013/02/26/aaronallen/.

${ }^{2}$ In addition to a long history as an activist, I also have a modest history of publication in this arena: see Aaron S. Allen,

"Institutional Change and Leadership in Greening the Campus," in Sustainability and University Life, ed. Walter Leal Filho (Frankfurt am Main \& New York: Peter Lang, 1999), 105-27.

${ }^{3}$ http://conference.aashe.org/2013/keynotes-and-plenaries.

${ }^{4}$ The diversity of approaches in ecomusicology is reflected in the conferences entitled "Ecomusicologies" (see www.ecomusicologies.org). See also Aaron S. Allen, "Ecomusicology," The Grove Dictionary of American Music (New York: Oxford University Press, 2013); by kind permission of Oxford University Press, the complete entry is provided at http://www.ecomusicology.info/.

${ }^{5}$ Here I am glossing Bohlman by using the capital M to indicate Charles Seeger's holistic and ecumenical sense of the scholarly fields represented throughout the diversity of primarily North American music studies, including music history, ethnomusicology, music theory, inter alia. By using "Musicology" or "Musicologist," I intend to be inclusive and to shorten what might otherwise be convoluted references to the disciplines and/or the individuals who study Western and non-Western musics using a great variety of methods (including but not limited to, the historical, paloegraphic, archival, anthropological, ethnographic, oral, theoretical, composititional, performative, computational, linguistic, biological, etc.).

${ }^{6}$ Philip V. Bohlman, “Musicology as a Political Act," The Journal of Musicology 11, no. 4 (Fall 1993): 419.

${ }^{7}$ Ibid., 436.
} 
Among those "Others" that Musicologists ignored, I propose that we should include the Earth itself. The "Earth as Other" is not just a postmodernist or new-musicological anthropomorphizing of the planet. By saying that the Earth has been "othered," I would like to suggest that we need a paradigm shift in order to include the Earth-the planet itself (or Gaia herself), the biotic life and abiotic contexts of the biosphere, the environmental insults humans have inflicted on it and each other, and the upheavals among human communities that result from such environmental and social exploitations-among topics now in the realm of study that were once excluded from the Musicological enterprise (as were Bohlman's "women, people of color, [and] the disenfranchised"). In a true pluralistic sense, practicing ecomusicologies can comfortably encompass, on the one hand, our studies of appealing representations of idealized nature and human reflection on nature (à la Beethoven's Symphony Pastorale.) ${ }^{8}$ On the other hand, ecomusicology can, and must, also engage with the profound environmental crises that threaten civilization. Musicologists have the capacities to understand those crises from alternative viewpoints and make some contributions, however small, to ameliorating them. ${ }^{9}$

This matter of making small contributions resonates with Paul Robbins's reflections on the field of political ecology, which he found was rather "hard to define" despite its widespread adoption and influence. ${ }^{10}$ After his extensive meditation on and research in the diverse field, he made two points that could benefit those of us thinking about and engaging in ecomusicology. First, "One need not be a political ecologist to mobilize the resources, or learn from the insights, of political ecology." ${ }^{11}$ In saying this, Robbins reminds us that we need not self-identify biographically as "ecomusicologists" or explicitly denote our work as "ecomusicology"; rather, ecomusicology is a tool that many can employ and that can benefit many, both inside and outside the academy, explicitly and implicitly. Second, Robbins recognizes that engaging in political ecology—or, by my extension, in ecomusicology—we are making a "small contribution to helping us all break from an image of a world where the human and the non-human are disconnected." ${ }^{12}$ Music studies in general, and ecomusicology in particular, do offer us ways to bridge

${ }^{8}$ While I do intend in this statement to be somewhat critical of such nostalgic or romanticizing studies, I am aware of and support the need for them as well. In fact, I have written such studies; see Aaron S. Allen, "Symphonic Pastorals," Green Letters 15 (2011): 22-42.

${ }^{9}$ In commenting on this introductory essay, Jeff Titon observed:

Ethnomusicologists usually take some credit for broadening the scope of music studies in Euro-America so that it has come to include, and respect, the musics of "others" and not just Western art music (a.k.a. classical music). Ethnomusicologist Bruno Nettl believes this is an expression of ethnomusicology's commitment to egalitarianism. Nettl, who has written extensively over the past 50 years about the field of ethnomusicology, its nature and history, makes this commitment a part of what he calls ethnomusicology's credo: "Fundamentally, ethnomusicologists are egalitarians. ... they regard all musics as equal ... [and] consider all musics worthy of study... believing that the teaching of their subject will in a small way promote intercultural—maybe even international—understanding, that it will combat ethnocentrism ..." I demur. Historically, our subject has been the music of "other" peoples and cultures; that is, the music of "not us." In my view, many of us have been guilty of the kind of colonialist otherizing that Edward Said called to the academic world's attention with his book Orientalism. We also are guilty of otherizing in the way a white, male dominated academic field has traditionally been guilty: racism, sexism, etc. For decades, some ethnomusicologists have been trying to mitigate these offenses, with mixed success.

See Bruno Nettl, The Study of Ethnomusicology, new edition (Urbana, IL: University of Illinois Press, 2005), 14-15; and Edward Said, Orientalism (New York: Pantheon Books, 1978).

${ }^{10}$ Paul Robbins, Political Ecology: A Critical Introduction (Chichester, UK: Wiley-Blackwell, 2012 ), 7.

${ }^{11}$ Ibid., viii.

${ }^{12}$ Ibid., 3. While Robbins provides a few partial definitions of political ecology—such as "a field that seeks to unravel the political forces at work in environmental access, management, and transformation" (3) — he ultimately settles on, and expands throughout his book, the idea that "political ecology is not a method or a theory, nor even a single perspective. Rather, [Robbins] suggest[s], political ecology is an urgent kind of argument or text (or book, or mural, or movie, or blog [or music, or sound?]) that examines winners and losers, is narrated using dialectics, begins and/or ends in a contradiction, and surveys both the status of nature and stories about the status of nature" (viii). His emphases—on political ecology's rather clear 
unfortunate nature-culture divides.

Most intellectual studies of music, as with ecomusicology, have a home in universities and colleges. These institutions are not, and should not be, exclusive places for such studies; one goal of our AASHE conversation was to stimulate the discussion outside traditional professional academic confines. ${ }^{13}$ Nevertheless, much ecomusicological dialogue does happen within the academy; those of us who are academics could stand to consider our intellectual homes more often, not only for the shelter and stimulation they provide, but also for the role they allow in effecting change. The act of engaging with our campus soundscapes, for example, ultimately connects us to larger pedagogical issues regarding the roles of environmental and music studies in the context of a liberal arts education. These concerns are not just about maintaining a place in the curriculum for music studies, for environmental studies, or for ecomusicological studies; rather, such concerns engage with fundamental questions about the role of all those pursuits in light of the still profound and unfortunate disconnect between the "two cultures" of C.P. Snow. First making his argument in 1950s England, Snow believed that Western society was split into literary intellectuals and physical scientists: "Between the two [exists] a gulf of mutual incomprehensionsometimes (particularly among the young) hostility and dislike, but most of all lack of understanding." The sentiment is still, unfortunately, common today. ${ }^{14}$

As with all of Musicology, ecomusicology is a political act, but its ramifications are of concern not only to the discipline(s) of music. Rather, ecomusicology fits into a larger context in the liberal arts as part of bridging those divided cultures that Snow derided; ultimately, ecomusicology is part of a transformation of education that seeks to create a more just and sustainable world through the work we do as teachers. As our field of action extends, via our students and research, from educational institutions into the public sphere of planning, management, policy, and even cultural thought, ecomusicology becomes activism.

engagement with environmental issues, difficulty in being defined, diverse approaches, and practitioners' belief in making a difference-further resonate with the field of ecomusicology.

${ }^{13}$ Applied ecomusicology indeed happens outside the academy, and Jeff, Denise, and I believe there is a developing and promising future for it. Michael Silvers has written two reviews of ecomusicology in mainstream journalistic sources, such as the New York Times, that have engaged (implicitly) with ecomusicology; see his "Ecomusicology in the News" in the Ecomusicology Newsletter 2, no. 2 (2013): 10; and 3, no. 1 (2014): 18-19. For a consideration of environmental issues in the context of popular music contexts see also Mark Pedelty, Ecomusicology: Rock, Folk, and the Environment (Philadelphia: Temple University Press, 2012). The Ecomusicology Bibliography (www.ecomusicology.info/bib) includes many reports of ecomusicological ideas and actions that take place outside the academy; see Aaron S. Allen and Miranda S. Freeman, "The Ecomusicology Bibliography via Zotero: A Dynamic and Emerging Scholarly Resource," Ecomusicology Newsletter 1, no. 1 (2012): 6-9.

${ }^{14}$ C. P. Snow, "The Two Cultures," in The Open Form: Essays for Our Time, ed. Alfred Kazin, 2nd ed. (New York: Harcourt Brace \& World, 1965), 36-49, at 39. See also Aaron S. Allen, "Ecomusicology: Bridging the Sciences, Arts, and Humanities," in Environmental Leadership: A Reference Handbook, ed. Deborah Rigling Gallagher (Thousand Oaks, CA: Sage Publications, 2012), 373-81, which considers ecomusicology in the context of the "two cultures." 


\section{Edited Transcript of the Plenary (Aaron S. Allen, Jeff Todd Titon, Denise Von Glahn)}

Aaron: To begin, I need to answer the obvious question that I'd say all but about five of you have.

\section{[General laughter.]}

Right? And that is, "What is ecomusicology?" A brief etymology is going to help me contextualize the definitions. The word is a portmanteau of ecocriticism and Musicology; taking a step back, the literary studies field known as ecocriticism connects ecology and criticism, while my discipline, Musicology, connects music and logos, this last of which is Latin for both "word" and "the study of." "Logos" is also part of the word ecology, which stems from the Greek oikos, meaning house or environment, a root it shares with economics. So putting these terms together, we might understand ecomusicology as the critical study of music and environment.

The term has not been around for very long, but the idea of connecting these concepts goes back at least as far as the ancient Greeks. I found the first use of the term in 1972, but it did not start gaining traction until the first decade of the twenty-first century. In 2010 I was asked to write a definition for the Grove Dictionary of American Music, ${ }^{15}$ but given the newness of the field and the centuries-long interest in the topic, and given the numerous related concepts in soundscapes, acoustic ecology, and romanticism, and given my own critical take on the term itself, it was, I must say, a challenging task. In the end, I built on the etymology I just shared and provided two succinct ideas. First, ecomusicology considers the interconnections between music, culture, and nature.

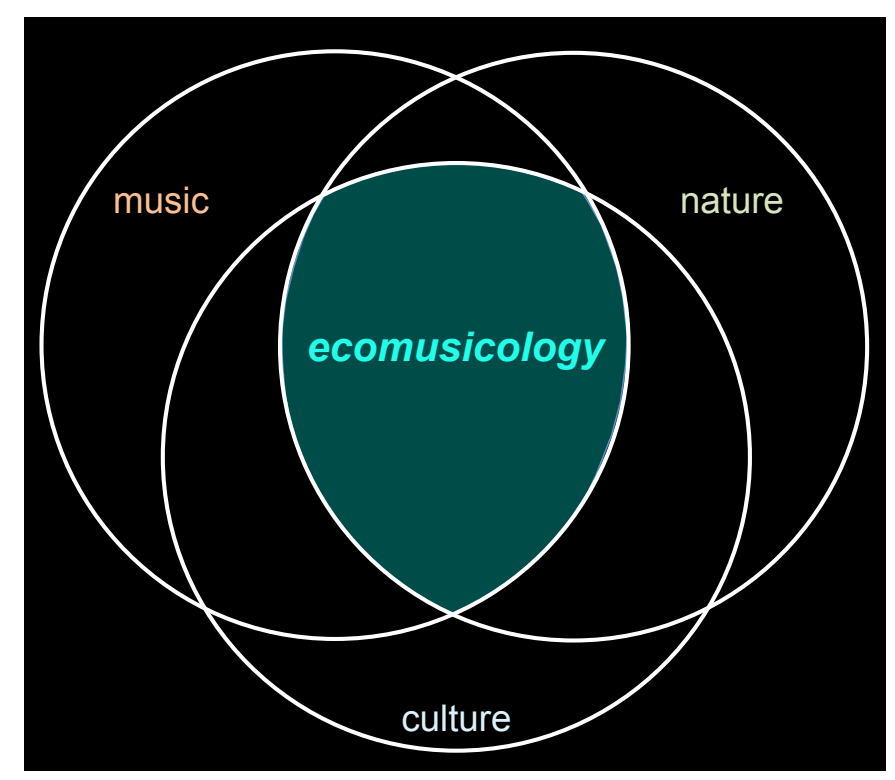

Figure 1

According to the Keywords of philosopher and literary scholar Raymond Williams, however, those terms are among the most complex in the English language. ${ }^{16}$ I'm sure you all are familiar with some of the

\footnotetext{
${ }^{15}$ Allen, "Ecomusicology."

${ }^{16}$ Raymond Williams, Keywords: A Vocabulary of Culture and Society (New York: Oxford University Press, 1985).
} 
many debates surrounding nature. ${ }^{17}$ Certainly, we must resist unnecessary dichotomies between nature and culture, between environments and humans, and we must necessarily fuse these concepts. Music can help us do that. But music itself is also a very complex term that has numerous meanings regarding meaningful or organized sound, especially depending on its human or nonhuman contexts.

So, in an attempt to slough off some of those terminological problems, I also provided a second definition for ecomusicology: ecomusicology considers the intersection of nonhuman sound worlds and human sound worlds, or the overlap of the physical and cultural environments as mediated through sound.

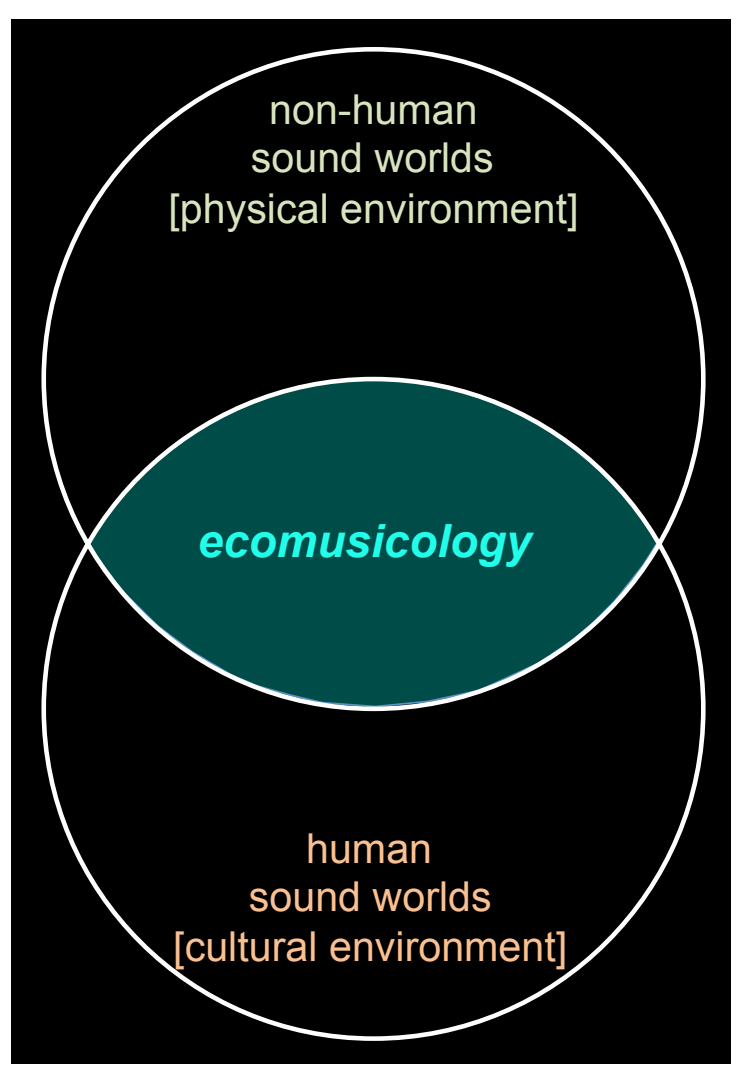

Figure 2

In this extremely broad definition of the approach, ecomusicology can be an umbrella for many diverse, complementary, and even opposed ways to examine the intersections of music, culture, and nature. There is no methodological rigor, nor should there be. ${ }^{18}$

Rather than a more rigid discipline, ecomusicology is a field, a place where many disciplines meet, much like environmental studies and much like sustainability, only here with an added interest in music and sound. Drawing on ecology, anthropology, geography, environmental history, and literary ecocriticism, ecomusicology is a subfield of Musicology. Now, Musicology is sometimes seen as an

\footnotetext{
${ }^{17}$ As but one example, consider Kate Soper, What Is Nature?: Culture, Politics, and the Non-Human (Oxford: Blackwell, 1998).

${ }^{18}$ In addition to Allen, "Ecomusicology," see also the six short pieces in Aaron S. Allen, Daniel M. Grimley, Alexander Rehding, Denise Von Glahn, and Holly Watkins, "Colloquy: Ecomusicology," Journal of the American Musicological Society 64, no. 2 (2011): 391-424.
} 
obscure discipline because it's the study of sound and music together with, rather than exclusively, the performance or composition of it. In mixing scientific, environmental studies with cultural, music studies, ecomusicology is a truly interdisciplinary field. ${ }^{19}$

This interdisciplinarity, however, is not an end in itself. Rather, it's a means for greater learning. Ecomusicology can bridge the arts and sciences and can teach creative critical thinking, for we need to remember that the environmental crisis is not just a crisis of science (failed engineering) but also a crisis of culture (failed thinking), so we need to muster all possible humanistic and scientific resources in order to imagine, understand, and confront it. ${ }^{20}$ This argument regarding human culture builds on work by Donald Worster, who acknowledged the accomplishments of science in understanding the environmental crisis, but noted that scientists have failed to understand those "why" questions that are rooted in culture. ${ }^{21}$ Ecomusicology can be a part of such efforts to understand and activate the role of human culture in confronting sustainability challenges.

To explain further, I'd like to make a brief parallel between sustainability and ecomusicology. Of course, this morning we'll be discussing how these two ideas are connected, but for now, I mostly want to make a heuristic comparison for the sake of our collective understanding.

As with ecomusicology, sustainability can be defined both as a binary and as a tripartite concept, and although there's widespread agreement on the basics of sustainability, there is simultaneously widespread disagreement on the use, deployment, and co-option of this very slippery term. Much of this debate comes from the beginnings of sustainability in the two-word phrase "sustainable development," which has, if not its origins, then its initial widespread dissemination in the Bruntland Report. ${ }^{22}$ This phrase brings up a number of problematic binaries for sustainability, such as earth and humans, environment and development, present and future, and even "more powerful" and "less powerful."

However, there are more recent elaborations on a tripartite definition of sustainability as distinct from sustainable development. You are all no doubt familiar with these models. One is the "three-legged stool" explanation of sustainability, which emphasizes economy, environment, and equity balancing an enduring world, one that supports humanity's place in, and as part of, nature. A second is a Venn diagram showing the overlap of economy, environment, and equity.

\footnotetext{
${ }^{19}$ The idea of ecomusicology as a "field," rather than a discipline, will be elaborated in a forthcoming collection of essays entitled Current Directions in Ecomusicology (Routledge), edited by Aaron S. Allen and Kevin Dawe.

${ }^{20}$ See Aaron S. Allen, "Prospects and Problems for Ecomusicology in Confronting a Crisis of Culture," Journal of the American Musicological Society 64, no. 2 (2011): pp. 391-94.

${ }^{21}$ As Donald Worster observes: "Natural science cannot by itself fathom the sources of the crisis it has identified, for the sources lie not in the nature that scientists study but in the human nature and, especially, in the human culture that historians and other humanists have made their study." The Wealth of Nature: Environmental History and the Ecological Imagination (New York: Oxford University Press, 1993), 27. Echoing Worster, Jill Conway, Kenneth Keniston, and Leo Marx write, "many, perhaps most, of our most pressing current environmental problems come from systemic socioeconomic and cultural causes and for this reason their solutions lie far beyond the reach of scientific or technical knowledge." Earth, Air, Fire, Water: Humanistic Studies of the Environment (Amherst: University of Massachusetts Press, 1999 ), 3.

${ }^{22}$ The Bruntland Report is the colloquial reference to the United Nations report, Gro Harlem Bruntland and the World Commission on Environment and Development, Our Common Future (New York: Oxford University Press, 1987).
} 


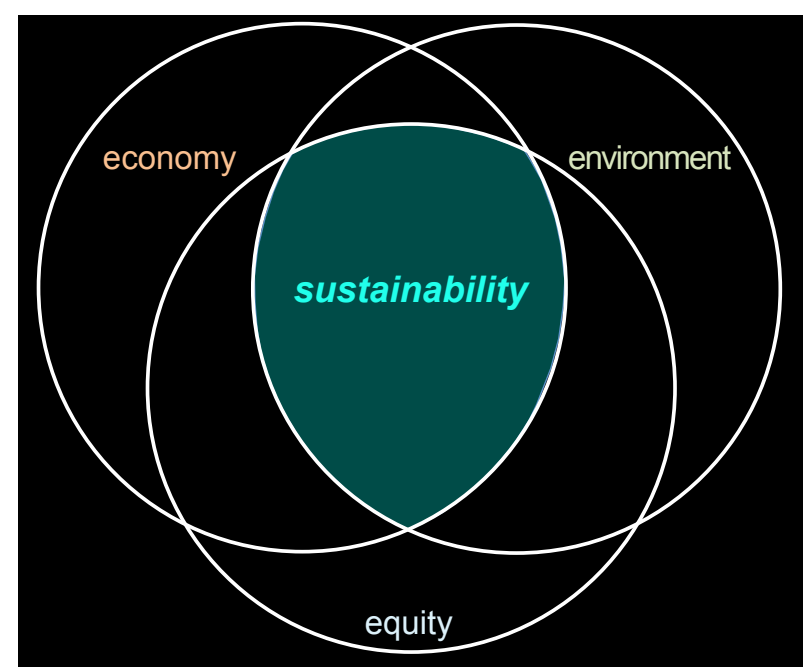

Figure 3

These two models are critiqued for giving equal roles to social and financial issues, when environment is usually understood as primary. This critique leads to a third model: three nested baskets, of which the largest is environment or ecology, the second largest is equity or society, and the smallest is economy or business. $^{23}$

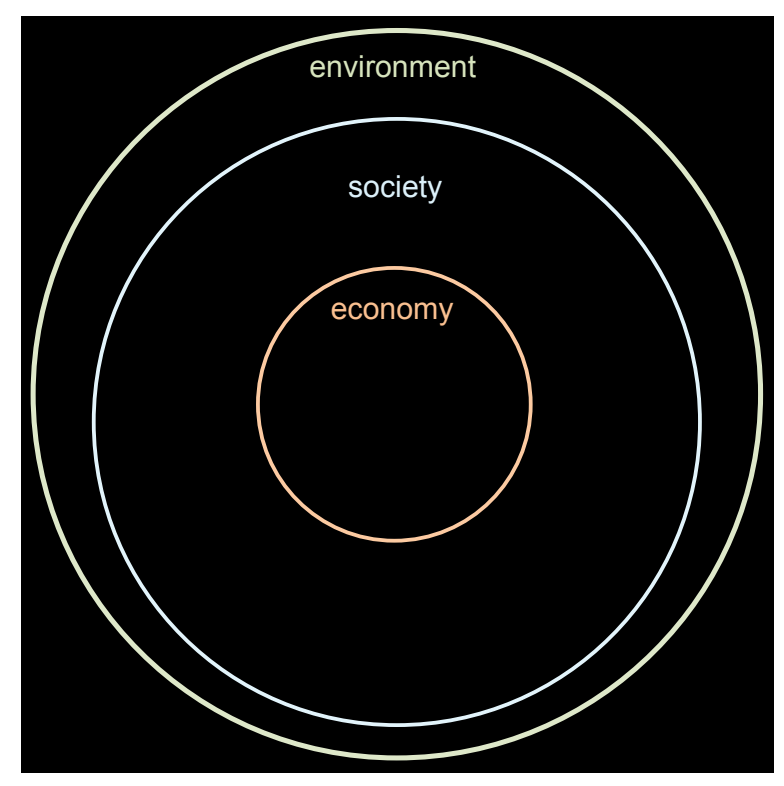

Figure 4

Just as with the elements of ecomusicology, there are debates around the meanings and relationships between these sustainability elements, and we're not going to get to the bottom of them anytime soon. Nevertheless, I'd like to propose a slightly more complex model that helps explain the relevance to sustainability of the arts and humanities in general and of ecomusicology in particular. In other words, in response to the question, "What does ecomusicology have to do with sustainability?", let me provide you

\footnotetext{
${ }^{23}$ Among the many sources describing sustainability, consider Robin Morris Collin and Robert W. Collin, Encyclopedia of Sustainability (Santa Barbara, CA: Greenwood Press, 2010).
} 
with a one-word answer: aesthetics. Put simply, aesthetics deals with philosophies of beauty, but it can be equally as complex as the terms I've just been discussing. Aesthetics in sustainability encourages us to ask, "What kind of world do we want to sustain?" My hope is that this world is not one that just considers environment, equity, and economics, but also one that includes joy, excitement, emotion, goodness, and beauty - a world that looks good, feels good, sounds good, and is good. Consider this a four-legged stool model of sustainability. Or you might think of it as a model of nested baskets that includes aesthetics. ${ }^{24}$

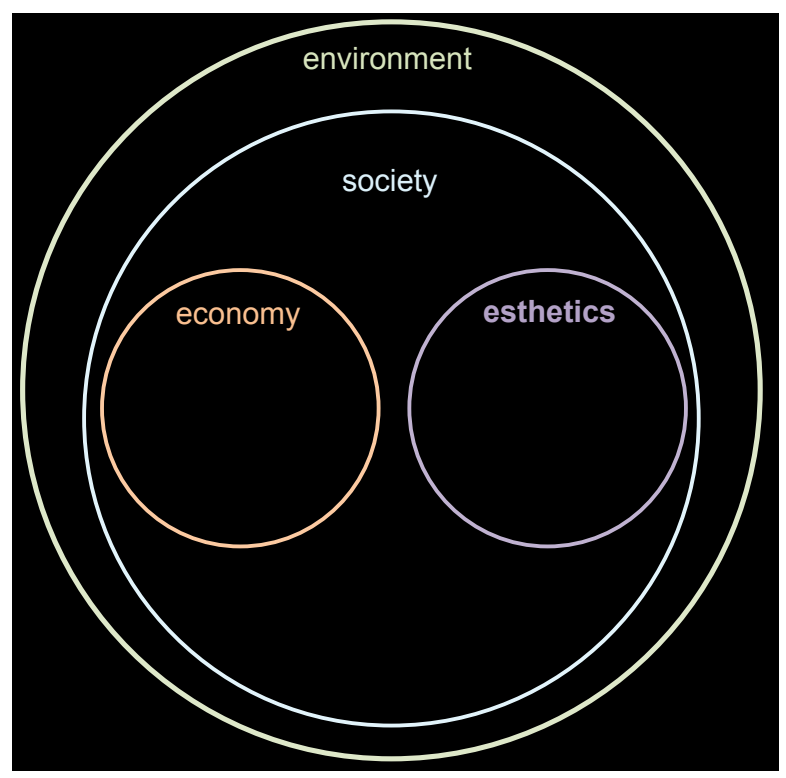

Figure 5

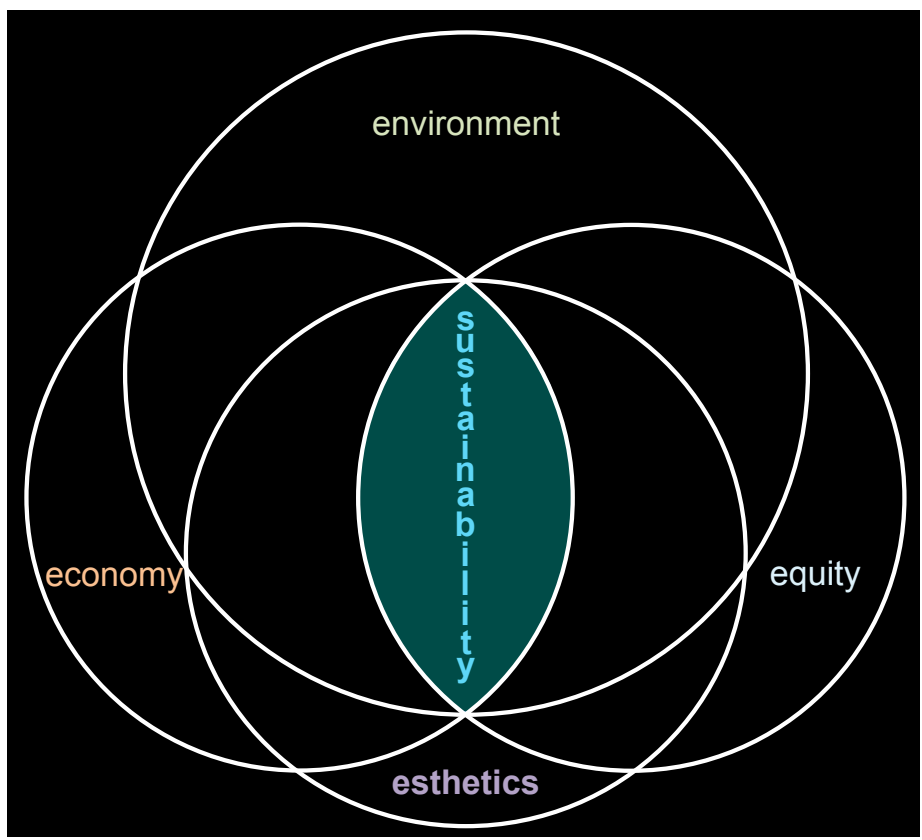

Figure 6

${ }^{24}$ This elaboration to a "four-legged" model is derived from the definition of sustainability provided by the Strategic Plan 2009-2014 of the University of North Carolina at Greensboro, uncgtomorrow.uncg.edu. 
So, ecomusicology connects with sustainability via aesthetics. But what roles can ecomusicology and aesthetics play in campus sustainability? While there can be many, I'd like to emphasize one multifaceted role in particular: education. As with many campus sustainability efforts, this is education that is both part of and supplementary to the curriculum.

Recent research in environmental and sustainability studies curricula has identified some challenges: namely, difficulty in integrating interdisciplinary knowledge and in educating students in problem solving and leadership. Clark and the other authors of this study suggest two things that environmental and sustainability studies programs should do: "employ an explicit, genuinely interdisciplinary analytical framework that facilitates the use of multiple methods to investigate and address environmental and social problems in context," and second, "provide students with the technical knowledge, powers of observation, critical thinking skills and management acumen required for them to become effective professionals and leaders." 25

Ecomusicology can be part of the effort to face the challenges that Clark and her colleagues laid out. Specifically, ecomusicology models an "interdisciplinary analytical framework" that can contribute particularly to the development of "powers of observation" and "critical thinking skills" in creative ways in order to help educate "effective professionals and leaders."

In short, inside the academy as part of a liberal arts education, ecomusicology can complement intellectual and practical engagements in environmental and sustainability studies to train students in imaginative, critical, and analytical thinking. ${ }^{26}$ Our students will take those forms of thinking outside the academy and put them into action. And of course, those of us who are more permanent denizens of the campus can contribute to and benefit from these new approaches as well. We all desire a better world, and creative, aesthetic experiences help us in imagining and effecting change. So much of what you all do as campus sustainability professionals can bridge the gap between the inside and outside of the academy, and we hope that considering music, sound, and ecomusicology will be one part of an aesthetic approach in sustainability.

This morning my colleagues and I will share some stories, ideas, and experiences about how to connect ecomusicology and sustainability. After some introductory comments from Denise and Jeff, the three of us will then spend about half an hour in an informal discussion addressing some key issues as they relate sound and sustainability. Overall our goal is to encourage you to consider aesthetic, sonic, and musical issues as you work toward achieving greater sustainability on campus. Inside and outside the academy, the aesthetic approach matters, because we want our communities to be adaptable, resilient, and sustainable, but we also want them to be beautiful places to live-we want the sustainable choices to be seen as the desirable choices, because they are ecologically appropriate, ethically just, economically responsible, and aesthetically pleasing. Incorporating considerations of music and sound into sustainability is one small step in that direction, but it is one that can engage community and help effect cultural change.

Thank you.

\footnotetext{
${ }^{25}$ Susan G. Clark et al., "College and University Environmental Programs as a Policy Problem (Part 1): Integrating Knowledge, Education, and Action for a Better World?," Environmental Management 47, no. 5 (May 2011): 701-15; and Susan G. Clark et al., "College and University Environmental Programs as a Policy Problem (Part 2): Strategies for Improvement," Environmental Management 47, no. 5 (May 2011): 716-26.

${ }^{26}$ See also Aaron S. Allen, "Ecomusicology: Music, Culture, Nature . . . and Change in Environmental Studies?", Journal of Environmental Studies and Sciences 2, no. 2 (2012): 192-20; and Allen, "Ecomusicology: Bridging the Sciences, Arts, and Humanities.”
} 


\section{[Applause.]}

Aaron: So we're moving into a slightly less formal stage of our discussion now. We do hope to have a trialogue between us, but we are going to get started first with Denise. She is going to introduce herself and tell you where she's coming from. So I'll just hand it over to Denise.

Denise: When I was first approached to participate in this session, I questioned my appropriateness for the task. What I do seems to sit far on the edges of what you all do: my work focuses on music, sound, nature, place, listening, and more recently on gender. But conversations with Aaron Allen and with Elizabeth Swiman, Director of Campus Sustainability at Florida State University, persuaded me otherwise.

Looking back, my connection to sustainability started when I was a very young child, and with my grandparents' summer cabin in what was then the woods of Huntington, Long Island.

After driving from the city on all kinds of paved highways, and then cutting off into an overgrown, rutted, dirt road that my father and grandfather had cleared through a stand of trees, we'd finally come within a hundred feet or so of the cabin, and I'd hear the sound of the pebbles that they'd strewn demarcating where we could park the car. I would listen for that sound the entire trip because it signaled that we'd arrived. To this day I hear it clearly in my memory. It remains one of my favorite sounds, because it is inseparable from the place where I would be free for a few weeks to get dirty, make mud pies, tromp through the woods, discover Indian peace pipes growing in clusters under the trees, hear all kinds of birds whose calls and songs didn't cross the acoustic threshold of my city row house, and just be. And all these sensations and promises were contained in the sound of crunching pebbles.

When I was in fifth grade, my classroom teacher, Mr. Norman Skliar, discovered and then encouraged my fascination with rocks. I collected them everywhere I went and lugged them to school. He and I tested them for hardness, and compared my specimens with those pictured in the Zim, Shaffer, and Perlman Guide to Familiar Minerals, Gems, Ores and Rocks. While he was interested in their content and what they told about the history of the earth, most of all I loved them for their shapes, colors, and sounds. No two looked or sounded the same. I knew which ones I had with me in my pocket by the way they clacked together.

Digging up rocks was part of my annual seed-planting ritual. Along with discovering new treasures, I anticipated seeing the first signs of life pushing through the soil; I was mesmerized by the invisibly slow emergence of a stem and then a tight bud, and then a flower. There was no sense of urgency; they didn't care about my impatience. There was a different rhythm and time scale in this world and I liked being a part of it, and getting into its groove. I was too young to connect my fascination with sound and time with music.

And then my sixth-grade teacher, Lorraine Heiser, gave me a copy of Walden. I was eleven years old. I didn't know what to make of it, but I sensed that the author had something to say to me, because he had a whole chapter titled "Sounds." I also figured it must be important because Mrs. Heiser had given it to me, and what my teacher valued, I valued.

A parallel track in my life was music. My parents had discovered me playing my older sister's piano lesson pieces when I was four or five years old. I'd heard Carol practicing and I mimicked what she did. I heard music on the radio and played it. Sounds seemed so easy to remember. They were clearly a way I understood my world. 
I continued my parallel existences loving rocks and listening to and making music, never giving much thought to how they might intersect until I was in high school and experienced the music of Charles Ives for the first time; and then in college I started writing about it. Ives was deeply attached to the places he lived, and one of the ways he understood those places was through their sounds. Perhaps it's no coincidence that I titled my first book The Sounds of Place. Ives heard people's feet on the pavement outside his Manhattan apartment and he made them music in a piece called "Over the Pavements"; he heard a river as it wended its way through Stockbridge, Massachusetts and created one of his most beloved pieces "The Housatonic at Stockbridge"; he heard the spontaneous polyphony of life that occurred around him while sitting on a park bench and wrote Central Park in the Dark; he heard echoes over a pond and titled the work Remembrance. He was a supreme listener. He understood that sounds were more than acoustical properties or pulsing information. Sounds contained places, and times, and values. And he preserved the sounds and the places in his music.

And I was sympathetic, literally, and heard what he was doing; and those sounds and his music found their way into my scholarship. I wrote a dissertation titled "Reconciliations: Time, Space, and the American Place in the Music of Charles Ives.” If I hadn't experienced a similar attachment to place through the sounds of crunching pebbles outside that treasured summer retreat, I wonder if I would have been able to hear what Ives was saying.

My most recent book is all about listening and how listening to nature brings nine American composers, all women, into a variety of relationships with their environments. Without knowing, when I started, exactly where my study would take me, the themes of listening and collaboration slowly but surely insisted upon themselves as an inseparable pairing. The composers saw themselves as collaborators with the natural world that inspired them, and they too preserved those places in their music.

Without having given it much thought years ago, it's become clear that music provides limitless opportunities for collaboration with the natural world; musicians collaborate every time we sound a note, or tap a rhythm: our instruments come out of the environment; the acoustic properties of our surroundings affect the sounds we hear; the humidity of the air changes the lengths of our strings and causes them to sag or tighten, or the wood to warp, or reeds to crack and dry out. Cold plays with the metals in our brass instruments. Musicians are in a constant conversation with the environment; it's part of the gig. And we must be most skillful listeners or we can't make our best music.

Music also calls attention to the uniqueness of the natural world in ways that are immediate but not always apparent. Music about places, especially, makes me want to preserve those places and their unique sounds. Music is my entry point into a number of questions related to sound, sustainability, and the environment:

1. How might a warmer world sound, is a question that perplexes me right now, and I'd welcome the opportunity to work with meteorologists or others who might help me understand the acoustic ramifications of global warming. 2. Will the increase in tropical forest blossoms caused by rising temperatures buffer sound? Or will additional bees and insects pollinating flowers mean more buzzing sounds? 3. Will melting ice caps and receding glaciers on iconic mountaintops make for a louder peak experience as sounds bounce off newly exposed rock? 4. We know that water is a great sound conductor: will increased rainfall make for more and more audible sounds? Or will high winds and flood waters destroy habitats, and further silence the spring that Rachel Carson noticed had gone mute? 5. Who gets to control our immediate soundscape, our regional one, the global one? 6. In an increasingly noisy world, where do we go for the quiet needed to hear our own thoughts? 
We live in a sounding world, and musicians are especially aware of that reality; our job is to attend to sound. Paying attention increases the value of everything we hear and reminds us of our place within this shared vibrating organism. Cultivating and nurturing this particular kind of attentiveness is what I do now as a teacher and a scholar. And a number of us are eager for the opportunity to do just that with folks beyond the confines of the academy and the concert hall.

\section{[Applause.]}

Aaron: Jeff, I wonder if you would follow Denise's model and look back on your career and your life and tell us how you got involved in sustainability. You've been writing on sustainability in the context of music and culture for six to seven years now, and very extensively at that, but you have a much longer engagement with sustainability. Would you share that with us?

Jeff: I was active in the environmental movement starting in the late '60s. I began becoming an organic gardener in the early 1970s. Practicing organic farming, cultivating, and thinking about providing a good soil, building up a good soil, were all very important hands-on experiences for me. Really what organic farmers are doing is sustainable farming, so it wasn't difficult to make the transition to thinking about sustainability from that. And some of you folks are probably old enough to remember the energy crisis in the 1970s and how we started moving to solar energy and wood heat. I did the same thing.

Aaron: And what were you studying at that time in school in your undergrad, and then in your graduate courses as you were working towards a Ph.D.?

Jeff: As you were saying, the idea of sustainability, like ecomusicology, has been around for a long time under related names-conservation is another name, an idea that overlaps to some extent. One that's more obscure is experimental morphology. ${ }^{27}$ When I was an undergraduate at Amherst College, I had the opportunity to study with a biologist, an embryologist, named Oscar Schotté, an experimental morphologist who had been a student of Ernst Haeckel. It was Haeckel who first introduced and defined the term "ecology." Schotté was particularly interested in the regeneration of tissue and limbs, starting this research just after World War I when so many soldiers were maimed, hoping to figure out how to give them a sustainable future. So that really was my first introduction, coming when I was about nineteen years old, to the idea of sustainability. I'll skip over graduate school for now. After that, I started teaching at Tufts University in the 1970s. I cofounded the American Studies program there and had a wonderful opportunity with other colleagues to invent and then team-teach the introductory American Studies course, which we called "History and Ecology in America." One of my colleagues, Ron Thornton, had been a high-energy physicist, but in the environmental movement of the 1970s he became a solar energy physicist. So we co-taught the course. Later a molecular biologist, Saul Slapikoff, joined us. It was unusual to have scientists teaching in American Studies, but the times were right for it. The environmental movement brought scientists and humanists together back then in a common cause, and it brings us together now.

\footnotetext{
${ }^{27}$ Experimental morphology is the experimental study of factors external to an organism on the organism's growth and form. Typically these are chemical or physical factors such as oxygen or light. See C. B. Davenport, Experimental Morphology (New York, Macmillan, 1897), 1:vii-viii.
} 


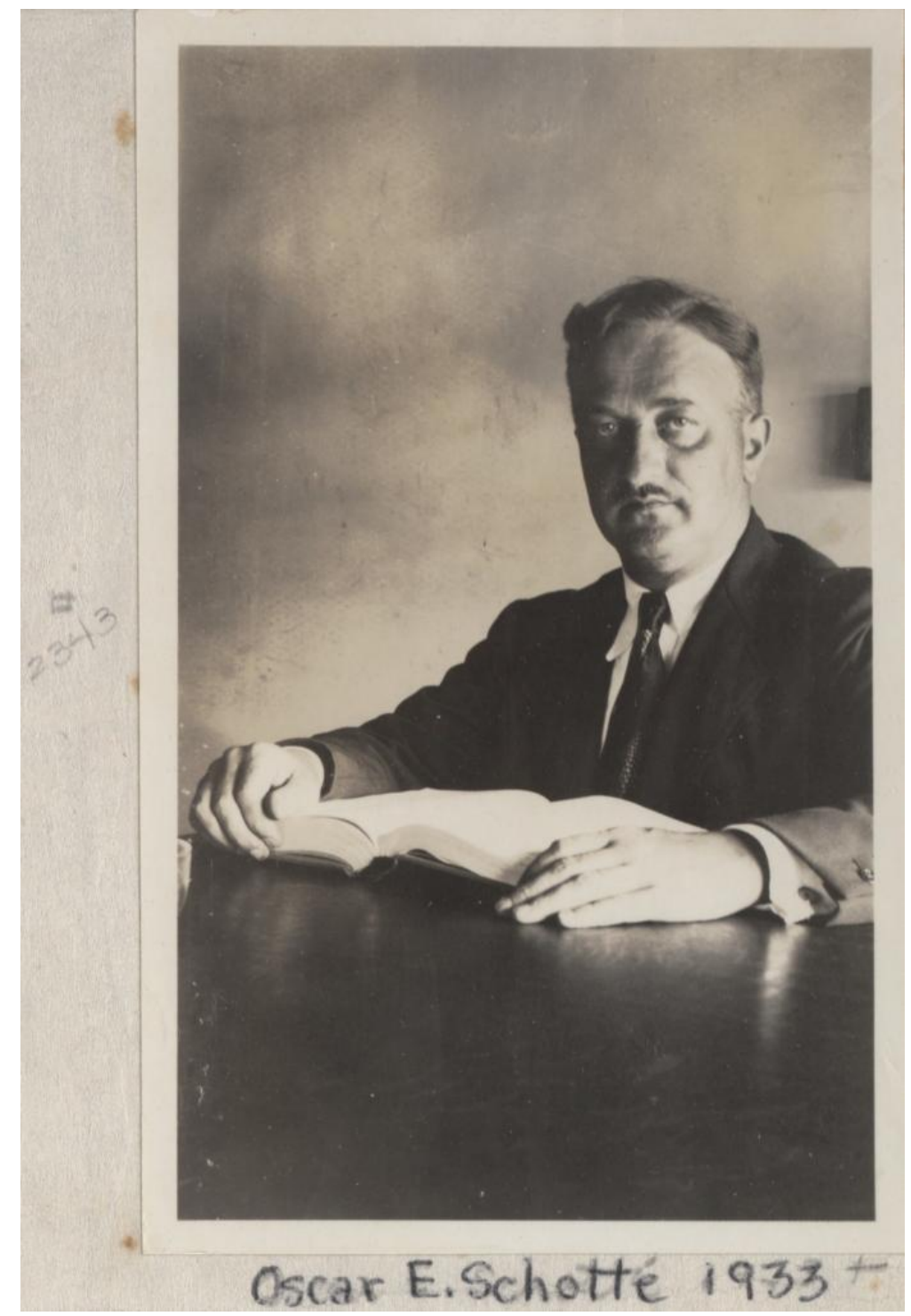

Figure 7: “Oscar E. Schotté”. Embryo Project Encyclopedia (1933). ISSN: 1940-5030 http://embryo.asu.edu/handle/10776/3173.

Aaron: That's interesting. You're working with a lot of scientists.

Jeff: Yes.

Aaron: And you're not majoring in science as an undergrad and you're not getting a Ph.D. in science.

Jeff: No.

Aaron: What is it that you're doing specifically in your academic track? And how is it that you found these relationships with sustainability and studying science? I think that we have a lot of students 
today who are doing something else, as you were doing, and who get involved a little bit with sustainability. I just wondered if you could elaborate on that.

Jeff: I was always encouraged to follow whatever interested me. I went to a liberal arts college where we were expected to know science, social science, history, literature, humanities, and I took it seriously. Why not? You have a problem or a question or a concept, and there are going to be many ways of approaching it. Just as there are many ways of approaching sustainability. Why not explore?

Aaron: Absolutely. And so much of education today and college education in particular is about tracking into pre-professional fields, and so many state measures have to do with job placement, and yet the liberal arts seems to be going by the wayside, which is one of my greatest concerns, especially because this is where I see ecomusicology really fitting in. Part of my argument is that ecomusicology doesn't work if we don't have a liberal arts environment. ${ }^{28}$ If we simply have a pre-professional environment we lose out on the kind of connections that you're talking about making that influence your work.

Jeff: I couldn't agree more. The kind of education I am describing at the college level is a kind of pre-professional amateuring, and I would encourage it. This is a time to be curious, to explore. Today in this era of growing income inequality, people are asking, "Why are we going to college?", and answering, "So we can get a good job." It's not education those people are after; it's training. You don't need college for that. How have we come to such a place? It's not college professors who've put us there. It's our nation's concentration on wealth accumulation, material wealth. Our society has made decisions which have made it very difficult to sustain liberal arts college education. And it's that same economic so-called rationality that's also led us to the environmental crisis.

Aaron: I listen very astutely to what you have to say because as an expert in American Studies, this is your world. You've studied a lot of American cultures, so when talking about America in general you have this wonderful background you can draw on. What are some of the particular areas of and groups in America that you've spent time studying?

Jeff: I've studied sound and the way sound sacralizes space in various places. Denise was talking about sound and place, which is very important: the particularity of sound to place. Detroit is one of those places for me. Appalachia is another. And when we think about the place we call America, our history books tell our children that this country was undeveloped land until settled by Europeans. They conveniently ignore the indigenous peoples who were here before us whose ideas about land and environment and trade were different and in many ways more sustainable. Our children read history books that say our ancestors fled Europe to settle in the New World to escape religious persecution. Really, most people came to the United States to make money, and we haven't stopped. It's made our lives unsustainable and it's caused the crisis in our economy and in the environment.

Aaron: Absolutely. I want to draw on something that you've written about. For those of you who

\footnotetext{
${ }^{28}$ See, for example, Allen, "Ecomusicology: Bridging the Sciences, Arts, and Humanities.”
} 
haven't looked at Jeff's biography in the program, there is a link to his blog, Sustainable Music. ${ }^{29}$ I highly recommend it. It's a lot of really in-depth thought about some of the things we're talking about but will only scratch the surface of today. I want to just pull out one line that you've written. You said, "Human beings should attempt to manage the soundscape as a sound commons, to permit all creatures to communicate with one another in their acoustic niches." ${ }^{30}$ Would you unpack that for us a little bit and give us a very quick primer on soundscapes and acoustic ecology and how they relate to sustainability regarding the idea of the sound commons?

Jeff: Although specialists debate finer points, the basic idea of soundscape-it's a back formation from landscape-has to do with the environment of sounds that surround living beings, and inorganic things too for that matter. So we're in a soundscape right here. Hear anything? You probably hear the sounds of breathing and maybe coughing. I don't hear a ventilator; you can usually hear a ventilator. So the soundscape is always with people who are hearing, and with all creatures. People are not aware of soundscapes very much. But of course if you think about it, each place has its characteristic sounds-the place that you live, your schoolroom, this building, the hotel where we're staying-where they're doing construction, some of you probably heard that. I think we can take some lessons from the natural world. One hundred fifty years ago Henry David Thoreau understood that species in the natural world adapted by more or less carving out a niche in which they could communicate through sound. Of course, sound isn't the only way through which creatures in the natural world communicate. They do it through sight and smell and touch too. But sound is a very important way: in terms of frequency and timbre-that's the tone quality that makes a trumpet and a piano playing a note of the same frequency sound different from each other-and in terms of duration and rhythm and silence and so forth, each species carves out its own particular niche in which to communicate with other members of that species. Today we call that the acoustic niche hypothesis. ${ }^{31}$ You're familiar with ecological niches? This is one of them. I think we need to manage soundscapes in the same way we try to manage landscapes. And I believe that we should think of the soundscape of the natural world as a commons. Who owns it? Nobody owns it. It is a commons, which is a shared resource. You are probably familiar with informational commons and digital commons and that sort of thing, but suppose we think of the acoustic environment as a sound commons. Now then, some people and corporations do try to own sounds and say that they're copyrightable as intellectual property just as ideas are copyrightable.

Does anybody have a birthday today? [Hand goes up.] What's your name? Andy? Let's sing "Happy Birthday" to Andy.

\section{[Crowd sings "Happy Birthday."]}

If someone recorded that and tried to publish it without permission, they'd be breaking the law. As you may know, the birthday song is copyrighted.

\footnotetext{
${ }^{29} \mathrm{http}$ ://sustainablemusic.blogspot.com.

${ }^{30} \mathrm{http}$ ://sustainablemusic.blogspot.com/2012/12/a-sound-commons-for-all-living-beings.html. See also Jeff Todd Titon, “A Sound Commons for All Living Creatures," Smithsonian Folkways Magazine, Fall/Winter 2012, http://www.folkways.si.edu/magazine/2012 fall winter/sounding off.aspx.

${ }^{31}$ Bryan C. Pijanowski et al., "Soundscape Ecology: The Science of Sound in the Landscape," BioScience 61, no. 3 (March 2011): 203-16. See also Bernard L. Krause, "The Habitat Niche Hypothesis: A Hidden Symphony of Animal Sounds," Literary Review 36, no. 1 (Fall 1992): 40-45.
} 


\section{[Gasps from the audience.]}

So people feel that sound can become private property and they can protect it through copyright, but I think it's better if we think of it as commons, as ideas and sounds in the natural world are, that we can share. We should manage the soundscape that way, as a commons.

Aaron: Thinking about the campus soundscape, and the places where many of us work and spend a lot of time, is in my experience not something that's often done. Those of you here who are sustainability managers who've done audits of your campus, ${ }^{32}$ who've participated in those type of activities, how many of you have done a soundscape analysis of your campus?

\section{[Only a couple hands go up in the audience, and one is singled out.]}

\section{Audience Member: Mark Pedelty!}

\section{Aaron, Denise, Jeff: Okay! All right! Excellent! Minnesota! Yes!}

Aaron: Mark should be here with us right now, of course.

Denise: His name came up earlier today.

Aaron: Campus soundscape analysis is not a common approach, but I think that it can be a useful approach in thinking about how people and nature intersect and interact on campus and where there could be potential problems with the way the built environment is functioning. For example, think about where and how HVAC units are located, when they are used, and who hears them; in considering their sonic impact, we must consider their use and need, and thus how buildings are designed so inefficiently, and how much energy is wasted. Sound can be an indicator for understanding what's happening on campus, and what's happening on campus is often a microcosm of bigger issues in the world. ${ }^{33}$ So we need to think about local soundscapes and think also about those common spaces where we all interact—we can close our eyes if we don't like the look of something, but we can't really close our ears. The soundscape of the campus matters as well.

Jeff: I would add to that: we have planners on campus who plan for the beauty of spaces, the aesthetics you were talking about, Aaron. This is our place, the campus. We want to make it as healthful as we possibly can. We shouldn't just consider the visual and the tactile. We should consider sound as well. There are many scientific studies of the effects of sound on health. In the 1970s the EPA made a number

\footnotetext{
${ }^{32}$ Regarding the campus environmental audit, see Sarah Hammond Creighton, Greening the Ivory Tower: Improving the Environmental Track Record of Universities, Colleges and Other Institutions (Cambridge, MA: MIT Press, 1998); Julian Keniry, Ecodemia: Campus Environmental Stewardship at the Turn of the 21st Century: Lessons in Smart Management from Administrators, Staff, and Students (Washington, D.C.: National Wildlife Federation, 1995); and April A. Smith, Campus Ecology: A Guide to Assessing Environmental Quality and Creating Strategies for Change (Los Angeles: Living Planet, 1993).

${ }^{33}$ See Creighton, Greening the Ivory Tower; Keniry, Ecodemia; and Smith, Campus Ecology.
} 
of studies in acoustic ecology and noise pollution. ${ }^{34}$ When you hear unpleasant sounds, do you know what happens? Your pulse begins to beat faster, you become more tense and nervous, your adrenaline begins to flow, and you get the fight-or-flight response. Imagine this happening to a whole population-wanting to fight or run away. And you can't help it. This is hardwired into your limbic system. It's not processed through the reasoning brain. This is resonance-what Denise was talking about when she spoke about vibrations. We live in a vibrating world; everything is vibrating. Your cells are vibrating right now. You may not know it, but they are. And the health of a soundscape can be measured by the extent of noise interference in it. The less noise interference, the healthier the soundscape. We can think about college campus soundscapes this way. I have a question for the audience: do you people feel any stress on your campuses?

\section{[Audience laughter indicating assent.]}

Jeff: How much of it might be related to sound? Wouldn't that be worth investigating? Thinking about? Planning about?

Aaron: In addition to sound, noise pollution, and problems of sound, we can also get unique sound in places that can also help us connect to that place ...

Jeff: Absolutely.

Aaron: ... through soundscapes, and also through musical works and composers. And I wonder, Denise, if you would speak a bit about how sound and music relate to place. You've written a whole book on it, so I know it's a big question, obviously, but ...

Denise: All places sound, and some places have inspired composers to write music in response. Sometimes the music directly incorporates or imitates the sounds of a place, and sometimes the music is more or less inspired by the place.

My first book was about music in the United States and the ways fourteen American composers, starting in the early nineteenth century, used musical references to large, iconographic natural places to identify themselves and the nation with nature. ${ }^{35}$ Where Europe had cities and palaces and museums, and ruins and reminders of ancient civilizations, the United States had nature in seemingly boundless supply. Rather than accept that nature was of lesser value than venerable cultural institutions, we became, in Perry Miller's words, "Nature's Nation." We made a virtue of the only thing we had. According to the storyline, we traversed, tamed, and eventually owned nature. The conquest narrative dominated dime-store novels. It gave us our first heroes. It fit most comfortably with men who were out in big nature doing the taming. My book considered music inspired by Niagara Falls, the Mississippi River, and the Grand Canyon,

\footnotetext{
${ }^{34}$ Noise Effects Handbook: A Desk Reference to Health and Welfare Effects of Noise (Washington, DC: U.S. Environmental Protection Agency, revised 1981), accessed December 3, 2013, http://www.nonoise.org/library/handbook/handbook.htm. See also the follow-ups to R. Murray Schafer's work on village soundscapes in the 1970s, in Helmi Järviluoma et al., eds., Acoustic Environments in Change \& Five Village Soundscapes (Joensuu, Finland: Tampereen ammattikorkeakoulu, 2009), which is reviewed in Allen, "Ecomusicology: Music, Culture, Nature."

${ }^{35}$ Denise Von Glahn, The Sounds of Place: Music and the American Cultural Landscape (Boston: Northeastern University Press, 2003).
} 
among other sites that became symbolic of the nation.

It was only while completing Sounds of Place that I appreciated thirteen of my fourteen composers were male. This, despite the fact that nature was regularly gendered female and discussed with feminine pronouns, "she" and "her." You'd think women's voices would have been in the foreground; but they weren't. I wondered what women composers had to say about "Mother Nature." A later book, Music and the Skillful Listener, focused on nine composers, all of them women. ${ }^{36}$ I was curious to listen to their music and hear what they valued. I wanted their perspectives on the ways nature informed their art and their sense of identity. What I discovered was that as women's access to nature and education increased over the twentieth century, women went from writing almost exclusively about small nature in intimate chamber genres to also writing about big nature in larger more "serious" genres. Mountains, big skies, and whales joined hermit thrushes, birch trees, and daisies as sources of inspiration. As women's worlds expanded so did the topics women were able to imagine; they listened to and composed it all. Never having felt fully a part of the conquest narrative that dominated the nation's consciousness in the nineteenth and early twentieth centuries, the composers didn't talk about nature in relation to the nation, and they showed no interest in owning or controlling nature. They saw themselves as part of a larger natural world and attended to it all. Their music preserves places in sounds. I hear it as a different kind of sustainable act.

The breadth and variety of their nature and place pieces reminds me of the importance of access, whether to nature or to education. Beyond a summer house with its promise of limitless nature adventures, when I think back on what and who shaped me, it's Mr. Skliar and Mrs. Heiser, two elementary school teachers, one who nurtured my fascination with rocks and another who gave me a book that few eleven year olds even know exists.

Jeff: Denise's story is very important. It raises the more general question, how does one come to love the natural world? How does one come to understand the importance of sustainability? Not everybody does. Nature study in elementary school is one way, but it's not done so much anymore. Yet it's terribly important.

Aaron: It's not even just about becoming connected to place to preserve those places; it's also about those places nourishing our relationships with them. It's a cycle that constantly will help us ...

Denise: It has to do with thinking of the soundscape as a commons. That we are all part of this place and it behooves us all to preserve the sounds of the place.

Jeff: And I wonder if what you're talking about with women composers isn't also true with women visual artists who in the nineteenth century were encouraged to become accomplished with still life, maybe some domestic landscapes, small-scale only. But I think of later artists like Georgia O'Keeffe who in the same way worked on a broader scale and understood that as a result of their seizing opportunities themselves and stepping outside of traditional gender roles in order to do that.

\footnotetext{
${ }^{36}$ Denise Von Glahn, Music and the Skillful Listener: American Women Compose the Natural World(Bloomington: Indiana University Press, 2013).
} 
Aaron: I wonder if we can take this discussion of place and move it towards climate change. From very small to very big. I wonder, Jeff, if you would connect for us the relationships of environmental issues in Appalachian music cultures, particularly with mountaintop removal, and some of the work that you've done there. ${ }^{37}$

Jeff: Yes, I'll try. When I first started thinking about sustainability, it was in terms of sustaining musical cultures and people making music. I wasn't really making the connections with the natural world that I should have been making. But suddenly I realized-in fact, ecomusicology has helped me to realize-these connections. They are very important and they are very powerful. Most of my colleagues working with cultural sustainability, which primarily means sustaining endangered traditional arts, don't really think about the environmental surround that is so critical to sustaining culture. Appalachia is a wonderful example of the dependence of culture upon environment. In the ethnographic work that I've done in the mountains of southeastern Kentucky, the inhabitants told me over and over again how attached they are to the place. Topophilia, love of place, is very strong there. Sound is a very important part of their attachment to place. The sound of their singing, the sound or their music echoing up and down the hills and hollows. Mountain top removal (MTR) — another acronym-MT—empty, empty—destroys the place, thereby destroying the sound; and it threatens the culture.

In terms of sound and sustainability, this is a destruction of the ecosystems that the people have made sacred by their singing. It's a catastrophic situation. I'll tell you a funny story—really, not so funny. I was speaking about this in New Orleans last October at the American Folklore Society conference there, just before the Ecomusicologies 2012 conference. I was telling folklorists, who are involved in the politics of the arts and cultural sustainability, that we mustn't confine ourselves to cultural threats. Economic threats and environmental threats to culture can be even more devastating. And two weeks after this conference, there was an earthquake that struck in eastern Kentucky. Local knowledge attributes this to mining and of course to mountain top removal. You've seen what happens with mountain top removal? How is this not going to disturb the earth down below it? Luckily my friends were not hurt. They said only the books at the local library were disturbed. Books fell off the shelves in the quake. I wondered which books fell off. Maybe Wealth of Nations.

\section{[General laughter.]}

In any case it was a remarkable lesson that culture depends on environment, that when one is disturbed so is the other; and the earthquake toppling the books symbolized it.

Aaron: Absolutely. The connection between supporting the musical traditions, the cultures of Appalachia, and supporting the place that they "sacralize" and that supports them in making their musical culture-we have to connect those issues to environmental issues. The politicization of those environmental issues will cause those people supporting the culture to shy away from the issues, to not

\footnotetext{
${ }^{37}$ Regarding climate change and MTR, see Travis D. Stimeling, "Music, Place, and Identity in the Central Appalachian Mountaintop Removal Mining Debate," American Music 30, no. 1 (2012): 1-29; Aaron S. Allen, "Environmental Changes and Music," in Music in American Life: An Encyclopedia of the Songs, Styles, Stars, and Stories that Shaped our Culture, ed. Jacqueline Edmondson (Santa Barbara, CA: Greenwood, 2013), 418-21; and Jeff Todd Titon's Sustainable Music blog, http://sustainablemusic.blogspot.com/2012/11/does-mountaintop-removal-cause.html.
} 
want to deal with them sometimes. We can all come together through supporting the arts, but when environmental issues start getting involved, then suddenly it becomes politicized and can divide us.

Jeff: It's very difficult for me to talk to my friends there in southeastern Kentucky and say to them, "Coal mining is a problem." When I do that, I'm reminded by them, gently. Their hands go on my shoulder and they say, "You must remember that our culture has been supported by coal mining for more than a hundred years." Economic rationality rears its ugly head here. I like the way that in your presentation your economics circle diminished to make room for aesthetics, Aaron. Really that's one of the areas where political action, if it is going to succeed, then we are going to have to come up with ways of sustaining the culture besides coal mining. I know in that geographical area that ecotourism has been one of the things put forward. I'm not sure how well it is succeeding.

Denise: I just wanted to comment. I spent twenty years in the Pacific Northwest, and what you see in Appalachia has a corollary in the Pacific Northwest with lumbering. You want to save trees, yet if you make any move in that direction then you come up against tree cutting and lumbering being essential to the economy of thousands of people. You can't stop that without basically impoverishing people immediately. So you've got to have something else besides just a prohibition on clear cutting.

Aaron: And that's where some of the technology issues come in-all the "i-gadgets" here on the table before us, which we all use today for music consumption, and music recording, and music dissemination. All of these have significant climate and environmental impacts through the materials that are in the gadgets themselves, where those materials come from, and the global warming gasses created by the electricity that they use. Of course we can take measures to address those things. Consider violin making, for example. We can preserve forests, which help sequester carbon, because their woods are used for musical instruments. In some places, those trees are sacred, essentially, and they provide certain kinds of woods that musicians value, and people value musicians who play those instruments, so it creates a cycle of value for certain kinds of music that we appreciate. At the same time there are other woods in those musical instruments that are endangered. I don't know what guitar you have with you today, Jeff, but if there is rosewood or ebony in it, these are often unsustainably harvested. Yet musicians, particularly musicians in Tennessee, where we are now-I'm sure some of you have heard of the issues of the Gibson guitars and some of the tropical woods they've been using-musicians demand these things because they have certain aesthetic values, and those values can cause problems: desiring them, creating demand for those tropical hardwoods, contributes to deforestation, human exploitation, climate change, and so on. In other words, this connection is not just between the place where the music is made or composed and then heard or consumed, but also between the technology that we use to make the music and environmental issues that are often one step, or many steps, removed from our immediate end use or enjoyment of the gadget, or guitar, or the violin. ${ }^{38}$

\footnotetext{
${ }^{38}$ Aaron S. Allen, “'Fatto di Fiemme': Stradivari's Violins and the Musical Trees of the Paneveggio," in Invaluable Trees: Cultures of Nature, 1660-1830, ed. Laura Auricchio, Elizabeth Heckendorn Cook, and Giulia Pacini (Oxford: Voltaire Foundation, 2012), 301-15. See also Aaron S. Allen, Kevin Dawe, and Jennifer C. Post, The Tree That Became a Lute: Musical Instruments, Sustainability and the Politics of Natural Resource Use (Urbana, IL: University of Illinois Press, forthcoming).
} 
Jeff: Absolutely. May I ask a question of Denise?

Aaron: Sure, sure!

Denise: This is not rehearsed, so I don't know what it's going to be!

\section{[General laughter.]}

Aaron: Very little is rehearsed!

Jeff: I insisted that it not be rehearsed ...

Denise: Yes ...

Jeff: ... or at least that I not be rehearsed.

\section{[General laughter.]}

Jeff: Denise, I know that you have taught listening. That's not something that many people are really teaching the way you are. I'm thrilled to hear that you're teaching listening and wondering if you could connect that to sustainability: the teaching of listening to sustainability.

Denise: I could try. I think it has to do with my belief that when I teach listening I am really teaching attentiveness. As a musician teaching musicians I want students to appreciate that it's not just music that we listen to. I want them to understand how much they can learn through sound. To know that there is infinite information available to them about their surroundings if they listen. And if they know their world through its sounds, there may be places they want to preserve because there are unique sounding environments. I guess it's another way of teaching caring. I have an assignment where I ask students to select a place and do nothing but listen to it for ten minutes. They write down what they hear.

Aaron: That has to be hard for a lot of students.

Denise: Very hard. They report that initially they are very squiggly. They find it hard to just focus on listening. Then I have them go back a second and then a third time and do the same thing. Finally I ask them, "Could you identify that place if all you could do was hear it?" Places have unique sounds, but we don't pay attention. We are accustomed to driving or walking and looking at landmarks, right? We remember landmarks. There are also what R. Murray Schafer refers to as "soundmarks," sounds that are important to a particular community. And we can remember them too.

Aaron: And Rachel Carson. ${ }^{39}$

\footnotetext{
${ }^{39}$ Rachel Carson, Silent Spring (Boston: Houghton Mifflin, 1962).
} 
Denise: Rachel Carson heard the silence, but she was listening; you can't hear the silence if you aren't listening. And you wouldn't know there was silence if you hadn't noted the sounds before. So I have a variety of exercises and assignments for increasing listening, attentiveness, and awareness. And I hope that they result in increased caring about the world we live in. I get many comments on year-end evaluations from students who point to their increased aural awareness as one of the most meaningful lessons they've learned. They thank me for forcing them to listen. One of the things I insist upon is getting ear buds out of their ears. You don't hear using only your ears; you hear with your entire body. You are depriving yourself of that when you plug your ears. You miss the space around the sound. I encourage them to lie on the floor, find that sweet spot between speakers. Take off your shoes. Close your eyes and let your whole body listen.

Aaron: Or go to live music.

Denise: Or go to live music, be with the music, and with other people who are listening with you. Your feet are wonderful listeners. My grandmother was deaf: she got a cold when she was seventeen years old that rendered her almost completely deaf. Yet she could tell me when someone was at the front door of her house because she felt them. She lived in a city row house that was all stone, so it wasn't that there was some kind of wood floor or siding that was vibrating. She felt their presence and made me very aware that she was hearing with parts of her body other than her ears.

Aaron: That is one of the main lessons we can take away. Through listening we can become aware, and through becoming aware we can truly care.

Denise: Absolutely, absolutely.

Aaron: I want to wrap up now and offer the opportunity for any of you to ask us questions.

Audience Member 1: So, simply sound seems to be different from music, especially in the context of noise pollution or heavy metal music. But I'm wondering when sound actually becomes music. When does that transformation happen, when does it switch from just simply sound to music?

Aaron: That's a great question, and we'd need an hour to answer it.

Denise: That wouldn't even do it. We talked about it last night and couldn't agree.

\section{[General laughter.]}

Aaron: Sorry to cut you off. It's really a complex issue, and it's very subjective.

Audience Member 1: Absolutely, thank you.

Denise: And your apologetic stance in regard to heavy metal, I think you should just cut that out. 
Audience Member 1: Yeah, that's just my paradigm.

Denise: That's fine.

Jeff: To get started, we wouldn't want to essentialize music. It's a cultural construct. Music is different for different cultural groups, and it's different for different individuals.

Denise: I also think it's going to be different now that we know that sometimes animals make sounds for pleasure. It's not just about mating or positioning. Sometimes birds sing because they like to sing. We had identified purely aesthetic pleasure as a unique characteristic of human music-making.

Aaron: Right, human exceptionalism.

Denise: Right, so now what do we do? If the aesthetic pleasure criterion makes human-generated sounds into music and birds sing for pleasure, then are birds making music? I would say, yes.

Audience Member 2: I love how you all talked about the sound of campus causing stress, and I was wondering if there were any types of programs or kinds of sounds or events that campus could hold to decrease that.

Aaron: Soundwalking. It's a well-established practice, and anybody can do it. Get a group of people, walk around and don't talk to each other and just listen. Then afterwards, talk to each other about what you heard-and that can create awareness. ${ }^{40}$

Denise: It can be a prescribed soundwalk. Someone can go out ahead of time and find particular sound environments and expose others to that or you can all just be surprised together.

Audience Member 3: I was wondering if you could connect ecomusicology to ecosemiotics and where music and language, and music as words, and music as communicating ideas come across, where that intersection is.

Aaron: Jeff, you've been thinking about this.

Jeff: Could you elaborate a little more on the question?

Audience Member 3: Yeah. If you look at semiotics, and you look at language and words as communicating an idea or a reality, then where does music, how does music communicate an idea, or a language, or music sounds or notes as communicated words or thoughts?

Jeff: This is a question that aestheticians have addressed for some time. One of the positions that philosophers of aesthetics have taken is that instrumental music is not representational in the way that

${ }^{40}$ Aaron S. Allen, “Active Listening via Soundwalks,” Ecomusicology Newsletter 2, no. 2 (2013): 14-15. 
words are. What does it consist of? Suzanne Langer wrote years ago that music represented the inarticulate flow of emotions, and she wasn't the first to make that point. Today that is how most people answer that question. Somehow for me it's not fully satisfying. The Baptists have their Bible and I have Thoreau. He wrote in the "Sounds" chapter of Walden — the book that Denise read when she was eleven years old-that sound speaks in a language without metaphor. That is to say, directly: sound communicates directly. But how are we prepared to understand that direct communication? I think we're prepared to experience it as co-presence in the world. That is, we experience the vibrations of sound as the presence of other beings in the world, and they experience us. We are co-present to each other in sound.

Audience Member 4: You said the term ecomusicology is a fairly new term. Certain artists, like John Denver, have a history of writing music that connects you to the environment. There are a lot of artists today under pressure in commercial music to get a lot of listeners. Do you think there is a movement among artists to write music to connect people with the environment?

Aaron: I think there are some aspects of sustainability that are being incorporated into concert promotions and touring, that's one thing. U2, for example, talks about it significantly, and then they have their tours that have dozens of tractor-trailer rigs that are going all around the country carrying their stuff. So there's a bit of a disconnect there, as there is with a lot of corporate sustainability issues. But I think for the artist, I don't know if there is a concerted effort to have them include environmental messaging in their songs. I would think that if they're doing it, then it's typically something they're interested in. Bruce Cockburn, the Canadian singer-songwriter, does it because it's what he believes in. ${ }^{41}$ John Denver did it because it is what he believed in; those were things that mattered to him. ${ }^{42}$ We mentioned Mark Pedelty earlier, and he's written a book on rock music and pop music and these very issues, called Ecomusicolgy. ${ }^{43}$ He looks at a lot of big bands and smaller bands, and some of the issues there. Some audiences simply say, "Hey! Don't mess up my fun time with the politics of environmentalism! Just leave me alone and let me enjoy my music!"

Denise: Other contemporary musicians who are aware include Nick Zammuto, Sigur Rós, and Sō Percussion.

Aaron: Oh yeah, there are lots of people, lots of groups.

Denise: I don't know if you are familiar with them, but I've learned from a doctoral student at FSU, Matt DelCiampo, that their music includes very conscious eco-messaging.

Rose: We've had a fascinating dialogue, and it's time for this session to end. Will you all be available for questions afterwards?

\footnotetext{
${ }^{41}$ Aaron S. Allen, "Bruce Cockburn: Canadian, Christian, Conservationist," in Political Rock, ed. Mark Pedelty and Kristine Weglarz (Burlington, VT: Ashgate, 2013), 65-90.

${ }^{42}$ David Ingram, The Jukebox in the Garden: Ecocriticism and American Popular Music Since 1960(Amsterdam, New York: Rodopi, 2010).

${ }^{43}$ Pedelty, Ecomusicology.
} 
All: Sure, yes.

Rose: And I also had a question for Jeff: Are you going to play your guitar?

Jeff: Well, I could ...

Rose: Could you do that as folks are leaving, so we could have the presence of sound as we're reconfiguring the room and people are exiting?

Aaron, Denise: They won't be listening, but...

\section{[Applause.]}

